\title{
Research of Work-Family Balance Based on Family Life Cycle
}

\author{
Shumin Yan, Yiwen Zhou \\ School of Economics and Management, Tongji University, Shanghai, China \\ Email: yanshumin@tongji.edu.cn, 13764203818@163.com
}

How to cite this paper: Yan, S.M. and Zhou, Y.W. (2016) Research of Work-Family Balance Based on Family Life Cycle. Open Journal of Social Sciences, 4, 218-224. http://dx.doi.org/10.4236/jss.2016.411018

Received: November 14, 2016 Accepted: November 23, 2016 Published: November 30, 2016

\begin{abstract}
This study examined the effect of different stages of Chinese family life cycle on work-family balance and the moderating effect of gender by using a sample of 352 employees in China. Reference to scholars in the division of the family life cycle, the study of the family life cycle is divided into six stages. We predicted and found that the family life cycle is significantly different in the effect of work-family enrichment and conflict.
\end{abstract}

\section{Keywords}

Family Life Cycle, Work-Family Conflict, Work-Family Enrichment

\section{Introduction}

Since the 1990s, China has entered the high-speed industrialization, marketization and urbanization era. Huge change in people's values occurred in the last three decades that people work for realization of personal values and for the improvement of life quality. Intense competition due to market economy makes employees face greater stress. In addition, due to traditional gender ideas in China that females pay more attention to family than males do, which leads to female employees have a disadvantage at the workplace. In today's China where traditional sexual view is being shocked, the study of gender in work-family filed is very meaningful.

\section{Review and Development of Hypotheses}

\subsection{Family Life Cycle}

Family life cycle theory originated from the family development theory of Evelyn Duvall (1957) [1] that families can grow and go through various stages, like people. In every stage of family life cycle, due to the particular task and requirements in each 
stage of the family, family factors such as population composition, age, and family burden make the difference. These tasks not only show the growth of family life cycle stage, but also deeply influence the pressure and demands of individuals in the family.

\subsection{Work-Family Balance}

There are two main perspectives and views in organizational behavior: one is focused on the negative role between work and family that is the study of work-family conflict (Greenhaus \& Beutell, 1985) [2]; another one is focused on the positive role, workfamily enrichment (Greenhaus \& Powell, 2006) [3].

Both conflict and enrichment have bidirectional sense, which means that work can positively or negatively affect to family andvice versa (Grzywacz \& Marks, 2000) [4]. In addition, Greenhaus and Beutell (1985) [2] thought work-family conflict can be analyzed through three dimensions: time-based conflict, strain-based conflict and behavior-based conflict. Carlson (2006) [5] structured a work-family enrichment model with six dimensions: bidirectional developmental resources, emotional resources and physical resources.

\subsection{The Influence of Family Factors on Work-Family Balance}

Byron (2005) [6] found that compared to other variables of family filed, family role stress and family role conflict affect work-family conflict most intensely. Shaffer (2001) [7] found married families have more family role stress and conflict than unmarried. One of the reasons is parenting stress. The greater the parenting load, the stronger work-family conflict perceived will be (Aryee, 1999) [8]. Netemeyer (1996) [9] and Rotondo (2003) [10] found that the number of children is one of the significant factors that influence work-family conflict. The bigger number of children is, the more workfamily conflict individual perceives. Research also suggested that the age of children is a significant variable that affects work-family conflict (Higgins \& Duxbury, 1994) [11]. Grzywacz (2002) [12] found that married individual perceives more work-family enrichment than the unmarried, and individual without children perceives more workfamily enrichment.

Different stages of family life cycle are corresponding to these characteristics. At different stages of family life cycle, the family's demand and couples' roles in the family will change, and individual's psychological and physiological condition will shift accordingly.

\section{Method}

We adopted a quantitative method for data collection. We sampled employees in several companies based in first-tier cities, like Shanghai and Beijing in China. We received questionnaire number is 412 and the size of effective sample is 352 .

Measures used in this study have been adapted from previous research. A brief description of each measure is provided below: 
Family life cycle. When measuring family life cycle, we mainly reference from models of Gilly \& Enis (1982) [13] and HongyanYu (2007) [14]. Schaningen and Danko (1993) [15] found that the model of Gilly \& Enis is superior to the others, and contains 99.5\% families in America. Combining Chinese national conditions, we choose the minimum age of family members as a classification standard, which is in line with the status quo of Chinese families that see children as the center. The age of the youngest child is classified into "0 to 6", "7 to 17 ", "over 18 ". Due to the purpose of this study, we remove the older family stage. Finally, we divide family life cycle into six stages like Table 1.

Work-family conflict. We applied the scale developed by Carlson (2006) [5], containing 18 items, 6 dimensions: time-based work-family conflict (WFTC); strain-based work-family conflict (WFSC); behavior-based work-family conflict (WFBC); timebased family-work conflict (FWTC); strain-based family-work conflict (FWSC); behavior-based family-work conflict (FWBC).

Work-family enrichment. We applied the scale developed by Hanying Tang \& HongyuMa (2009) [16], which is recognized for fitting the situation in China. It contains 14 items, 4 dimensions: work-family instrumental enrichment (WFIE); workfamily psychological enrichment (WFPE); family-work instrumental enrichment (FWIE); family-work psychological enrichment (FWPE).

All the scale are Likert five point scored. The coefficients of Cronbach $\alpha$ of workfamily conflict is 0.904 and of work-family enrichment is 0.898 , showing that both of the scales have good reliability consistency; The coefficients of KMO are both over 0.7 , Bartlett sphere inspection results Sig are less than 0.01, showinghigh validity.

\section{Results}

\subsection{Descriptive Statistics}

Table 2 suggests the distribution of six different stages of family life cycle. The male to female ratio is 0.98 . Respondents' age is mainly distributed between 20 - 45 years old, accounted for $89.5 \%$.Looking the marital status, unmarried is accounted for $34.9 \%$. Most of respondents have college degree or above.

\subsection{ANOVA}

Table 3 and Table 4 provide supportive results testing the influence of family life cycle

Table 1. Division of family life cycle.

unmarried

Young couple without child

Growing period (the age of the youngest child is 0 to 6 )

Educating children period (the age of the youngest child is 7 to 17)

Mature period (the age of the youngest child is over 18)

Launching children Stage 
Table 2. Sample characteristics.

\begin{tabular}{ccc}
\hline & Total No. & Percentage of Total (\%) \\
\hline unmarried & 172 & 48.9 \\
Young couple & 31 & 8.8 \\
Growing period & 71 & 20.2 \\
Educating children period & 41 & 11.6 \\
Mature period & 26 & 7.4 \\
Launching children Stage & 11 & 3.1 \\
Total & 352 & 100.0 \\
\hline
\end{tabular}

Table 3. Analysis of variance of work-family conflict.

\begin{tabular}{|c|c|c|c|c|c|c|}
\hline & & Sum of Squares & Df & Mean Square & $\mathrm{F}$ & Sig. \\
\hline \multirow{3}{*}{ WFTC } & Between Groups & 18.427 & 11 & \multirow{3}{*}{$\begin{array}{l}1.675 \\
0.617\end{array}$} & \multirow{3}{*}{2.716} & \multirow{3}{*}{0.003} \\
\hline & Within Groups & 133.829 & 217 & & & \\
\hline & Total & 152.256 & 228 & & & \\
\hline \multirow{3}{*}{ FWTC } & Between Groups & 11.393 & 11 & \multirow{3}{*}{$\begin{array}{l}1.036 \\
0.521\end{array}$} & \multirow{3}{*}{1.988} & \multirow{3}{*}{0.031} \\
\hline & Within Groups & 113.08 & 217 & & & \\
\hline & Total & 124.473 & 228 & & & \\
\hline \multirow{3}{*}{ WFSC } & Between Groups & 28.924 & 11 & \multirow{3}{*}{$\begin{array}{l}2.629 \\
0.521\end{array}$} & \multirow{3}{*}{5.047} & \multirow{3}{*}{0} \\
\hline & Within Groups & 113.053 & 217 & & & \\
\hline & Total & 141.977 & 228 & & & \\
\hline \multirow{3}{*}{ FWSC } & Between Groups & 29.967 & 11 & \multirow{3}{*}{$\begin{array}{l}2.724 \\
0.426\end{array}$} & \multirow{3}{*}{6.398} & \multirow{3}{*}{0} \\
\hline & Within Groups & 92.393 & 217 & & & \\
\hline & Total & 122.36 & 228 & & & \\
\hline \multirow{3}{*}{ WFBC } & Between Groups & 21.746 & 11 & \multirow{3}{*}{$\begin{array}{l}1.977 \\
0.516\end{array}$} & \multirow{3}{*}{3.829} & \multirow{3}{*}{0} \\
\hline & Within Groups & 112.041 & 217 & & & \\
\hline & Total & 133.787 & 228 & & & \\
\hline \multirow{3}{*}{ FWBC } & Between Groups & 12.021 & 11 & \multirow{3}{*}{$\begin{array}{l}1.093 \\
0.361\end{array}$} & \multirow{3}{*}{3.028} & \multirow{3}{*}{0.00} \\
\hline & Within Groups & 78.313 & 217 & & & \\
\hline & Total & 90.335 & 228 & & & \\
\hline
\end{tabular}

Table 4. Analysis of variance of work-family enrichment.

\begin{tabular}{|c|c|c|c|c|c|c|}
\hline & & Sum of Squares & Df & Mean Square & $\mathrm{F}$ & Sig. \\
\hline \multirow{3}{*}{ WFIE } & Between Groups & 16.79 & 11 & \multirow{3}{*}{$\begin{array}{l}1.526 \\
0.225\end{array}$} & \multirow{3}{*}{6.777} & \multirow{3}{*}{0} \\
\hline & Within Groups & 48.878 & 217 & & & \\
\hline & Total & 65.668 & 228 & & & \\
\hline \multirow{3}{*}{ WFPE } & Between Groups & 21.969 & 11 & \multirow{3}{*}{$\begin{array}{l}1.997 \\
0.378\end{array}$} & \multirow{3}{*}{5.278} & \multirow{3}{*}{0} \\
\hline & Within Groups & 82.107 & 217 & & & \\
\hline & Total & 104.076 & 228 & & & \\
\hline \multirow{3}{*}{ FWIE } & Between Groups & 39.18 & 11 & \multirow{3}{*}{$\begin{array}{l}3.562 \\
0.308\end{array}$} & \multirow{3}{*}{11.581} & \multirow{3}{*}{0} \\
\hline & Within Groups & 66.739 & 217 & & & \\
\hline & Total & 105.918 & 228 & & & \\
\hline \multirow{3}{*}{ FWPE } & Between Groups & 27.208 & 11 & \multirow{3}{*}{$\begin{array}{l}2.473 \\
0.309\end{array}$} & \multirow{3}{*}{8.011} & \multirow{3}{*}{0} \\
\hline & Within Groups & 67 & 217 & & & \\
\hline & Total & 94.208 & 228 & & & \\
\hline
\end{tabular}


on work-family enrichment ( $\mathrm{p}<0.05)$. Family life cycle has significant influence on the dimensions of work-family conflict and work-family enrichment. Figure 1 shows the work-family conflict and enrichment in different stages of Family life cycle.

Combining the results of work-family enrichment and work-family conflict, we found the degree of work-family enrichment of growing period is not obvious, while the degree of work-family conflict is the strongest, thus employees in growing period face more imbalance of work and family. On the contrary, the degree of work-family enrichment of single individuals is quite obvious and the degree of work-family conflict is pretty slight, thus it is easier for unmarried employees to obtain the work-family balance.

In terms of marriage, try to rule out other factors (such as: children), only considering the influence of marriage on work-family balance, so we choose to compare the unmarried and young couples family. Marriage in fact does not significantly affect work-family enrichment, while marriage has significant influence on work-family conflict, and married family perceived more work-family conflict than single person.

In terms of children, we find that children's growth process has significant influence on work-family enrichment. When Children are $7-17$ years old, the couples perceive the most obvious work-family enrichment. Children's growth process also has significant influence on work-family conflict. When children are very young, the couples perceive the most obvious work-family conflict, related with the stress of raising children and family role conflict when family faces huge pressure to parenting, for preschool children need parents to pay much time and energy, and certainly cause huge economic pressure to household spending.

\section{Limitations of the Present Study and Recommendations for Future Research}

The present study provided a number of insights into the relation between gender, family life cycle and work-family balance. The results of this study suggest that different stages of family life cycle make an important difference to employees' perceived workfamily balance. Through studying the moderating effect of gender, the results overturn the traditional idea that female employees face more work-family imbalance.

Nevertheless, the research had several limitations. One limitation of this study is that

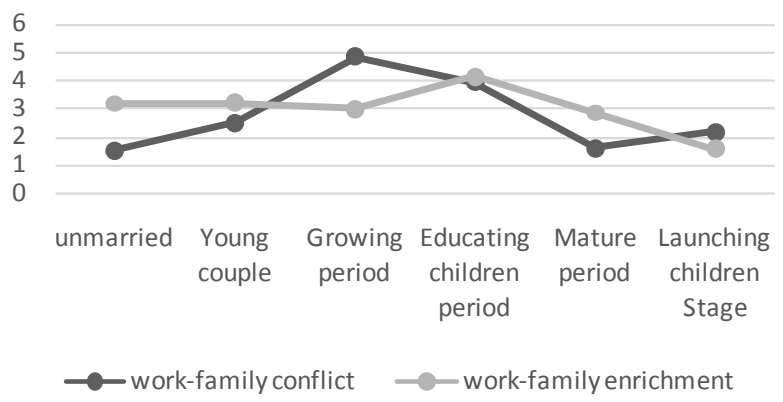

Figure 1. Statistical significance of work-family conflict and enrichment. 
the sample we selected is in first-tier cities in China. There may be different results for the samples in other cities or towns. A second limitation could be the family life cycle model we choose. We missed the discussion of situation of divorce and single parent. Future research could develop more comprehensive family life cycle and explore the relationship between family factors and work-family balance.

\section{Acknowledgements}

I acknowledge with thanks the financial support given to this work by Humanities and social science interdisciplinary projects of Tongji University, study on work-family balance based on two-child policy (1200219330).

\section{References}

[1] Duvall, E.M. (1957) Family Development. J. B. Lippincott, Philadelphia.

[2] Greenhaus, J.H. and Beutell, N.J. (1985) Sources of Conflict between Work and Family Roles. Academy of Management Review, 10, 76-88.

[3] Greenhaus, J.H. and Powell, G.N. (2006) When Work and Family Are Allies: A Theory of Work-Family Enrichment. Academy of Management Review, 31, 72-92. https://doi.org/10.5465/AMR.2006.19379625

[4] Grzywacz, J.G. and Marks, N.F. (2000) Reconceptualizing the Work-Family Interface: An Ecological Perspective on the Correlates of Positive and Negative Spillover between Work and Family. Journal of Occupational Health Psychology, 5, 111-126. https://doi.org/10.1037/1076-8998.5.1.111

[5] Carlson, D.S., Kacmar, K.M., Wayne, J.H. and Grzywacz, J.G. (2006) Measuring the Positive Side of the Work-Family Interface: Development and Validation of a Work-Family Enrichment Scale. Journal of Vocational Behavior, 68, 131-164. https://doi.org/10.1016/j.jvb.2005.02.002

[6] Byron, K. and Byron, K. (2005) A Meta-Analytic Review of Work-Family Conflict and Its Antecedents. Journal of Vocational Behavior, 67, 169-198. https://doi.org/10.1016/j.jvb.2004.08.009

[7] Fu, C.K. and Shaffer, M.A. (2001) The Tug of Work and Family: Direct and Indirect Domain-Specific Determinants of Work-Family Conflict. Personnel Review, 30, 502-522. https://doi.org/10.1108/EUM0000000005936

[8] Aryee, S., Luk, V., Leung, A. and Lo, S. (1999) Role Stressors, Inter Role Conflict, and WellBeing: The Moderating Influence of Spousal Support and Coping Behaviors among Employed Parents in Hong Kong. Journal of Vocational Behavior, 54, 259-278. https://doi.org/10.1006/jvbe.1998.1667

[9] Netemeyer, R.G., Boles, J.S. and McMurrian, R. (1996) Development and Validation of Work-Family Conflict and Family-Work Conflict Scales. Journal of Applied Psychology, 81, 400-410. https://doi.org/10.1037/0021-9010.81.4.400

[10] Rotondo, D.M., Carlson, D.S. and Kincaid, J.F. (2003) Coping with Multiple Dimensions of Work-Family Conflict. Personnel Review, 32, 275-296. https://doi.org/10.1108/00483480310467606

[11] Higgins, C. and Lee, C. (1994) Impact of Life-Cycle Stage and Gender on the Ability to Balance Work and Family Responsibilities. Family Relations, 43, 144-150.

https://doi.org/10.2307/585316 
[12] Grzywacz, J.G. (2002) Toward a Theory of Work-Family Enrichment. 34th Annual Theory Construction and Research Methodology Workshop, Houston.

[13] Gilly, M.C. and Enis, B.M. (1982) Recycling the Family Life Cycle: A Proposal for Redefinition. Advances in Consumer Research, 9, 271-276.

[14] Yu, H.Y. and Liu, Y.B. (2007) The Modeling and Empirical Research of Family Life Cycle Model in China. Journal of Management Sciences, 20, 45-53.

[15] Schaninger, C.M. and Danko, W.D. (1993) A Conceptual and Empirical Comparison of Alternative Household Life Cycle Models. Journal of Consumer Research, 19, 580-594. https://doi.org/10.1086/209324

[16] Tang, H.Y. and Ma, H.Y. (2009) Development of Work-Family Enrichment Questionnaire and Research on Its Validity and Reliability. Advances in Psychological Science, 5, 852-858.

Submit or recommend next manuscript to SCIRP and we will provide best service for you:

Accepting pre-submission inquiries through Email, Facebook, LinkedIn, Twitter, etc. A wide selection of journals (inclusive of 9 subjects, more than 200 journals)

Providing 24-hour high-quality service

User-friendly online submission system

Fair and swift peer-review system

Efficient typesetting and proofreading procedure

Display of the result of downloads and visits, as well as the number of cited articles Maximum dissemination of your research work

Submit your manuscript at: http://papersubmission.scirp.org/

Or contact jss@scirp.org 